\title{
Implementasi Metode Fuzzy Time Series untuk Peramalan Jumlah Pengunjung di Benteng Fort Rotterdam
}

\author{
Vivianti*, Muhammad Kasim Aidid, \& Muhammad Nusrang \\ Program Studi Statistika, Fakultas Matematika dan Ilmu Pengetahuan Alam, Universitas Negeri Makassar, Indonesia
}

Keywords: Fuzzy, Time Series, Peramalan, Fort Rotterdam

\begin{abstract}
:
Peramalan merupakan kegiatan yang dilakukan untuk memprediksi nilai suatu variable di waktu yang akan datang. Tujuan dari penelitian ini adalah mengimplementasikan Metode Fuzzy Time Series untuk memprediksi jumlah Pengunjung Benteng Fort Rotterdam. Metode Fuzzy Time Series adalah sebuah metode peramalan yang menggunakan himpunan Fuzzy sebagai dasar dalam Proses prediksi. Tahapan Peramalan dalam penelitian ini adalah mendefinisikan semesta pembicaraan U, menentukan jumlah dan Panjang kelas interval, defuzzifikasi dan mendefenisikan himpunan Fuzzy pada U, melakukan Fuzzifikasi pada data jumlah pengunjung, menentukan Fuzzy logic relationship (FLR), membentuk Fuzzy Logical Relationship Group (FLRG), melakukan defuzzifikasi, dan melakukan perhitungan peramalan. Dalam meramalkan jumlah Pengunjung di Benteng Fort Rotterdam dengan menggunakan Metode Fuzzy Time Series diperoleh hasil peramalan sebanyak 16240,35 atau dibulatkan menjadi 16240 Pengunjung pada bulan selanjutnya, dengan nilai MAPE sebesar 119,93 dan RMSE sebesar 4739,08.
\end{abstract}

\section{Pendahuluan}

Sektor yang saat ini turut menjadi perhatian pemerintah untuk dikembangkan adalah Sektor Pariwisata. Sektor Pariwisata akan berdampak pada penambahan pendapatan devisa baik untuk negara secara khusus maupun masyarakat setempat secara umum. Sehingga dapat dikatakan Sektor pariwisata memiliki peran sangat penting untuk menunjang perekonomian Indonesia. Kepala Badan Koordinasi Penanaman Modal (BKPM) Thomas Lembong dalam rapatnya dengan Presiden Joko Widodo, mengatakan bahwa Pariwisata menjadi sektor yang dapat diunggulkan karena mayoritas berada disektor jasa, selain itu pariwisata merupakan komoditas yang berkelanjutan dan menyentuh hingga ke level paling bawah masyarakat (Ibo, 2018).

Dampak positif sektor pariwisata dapat menguntungkan Indonesia sebagai negara yang memiliki banyak keunikan baik dari segi budaya maupun tempat wisata yang indah. Menteri Pariwisata dan Ekonomi Kreatif, Mari Elka Pangestu mengungkapkan bahwa Kekuatan Indonesia dalam sektor pariwisata berada pada sumber daya budaya dan sumber daya alam, sebagai aset yang bisa di promosikan (Nawangwulan, 2014). Salah satu tempat wisata yang menawarkan sumber daya budaya dan sejarah yang ada di Kota Makassar adalah Benteng Fort Rotterdam. Walaupun letaknya di Makassar, Sulawesi Selatan, kawasan cagar budaya Benteng Fort Rotterdam termasuk aset kepemilikan nasional dalam hal ini Kementrian Pendidikan dan Kebudayaan. Dimana unit pelaksana di kawasan tersebut adalah Balai Pelestarian Cagar Budaya (BPCB) Makassar yang berkantor di kawasan benteng. Unit inilah yang kemudian secara teknis pelaksanaan diberikan tanggung jawab untuk menjaga maupun mengurus pemeliharaan

\footnotetext{
* Corresponding author.

E-mail address: aditio.putra@gmail.com
} 
Benteng Fort Rotterdam. Pengunjung Benteng Fort Rotterdam mengalami peningkatan jika dilihat dari tahun 2012 hingga tahun 2016, yaitu 185.063 menjadi 240.725 (Kassa, 2018).

Salah satu cara untuk memprediksi dengan menggunakan data time series adalah dengan menggunakan analisis time series. Wei (2006) bahwa analisis time series deret waktu adalah urutan pengamatan yang teratur. Meskipun pemesanan biasanya melalui waktu, terutama dalam hal interval waktu yang sama, pemesanan juga dapat dilakukan melalui dimensi lain, seperti ruang. Menurut Aswi dan Sukarna (2006) analisis time series merupakan serangkaian data pengamatan yang terjadi berdasarkan indeks waktu secara berurutan dengan interval waktu tetap. Analisis time series adalah salah satu prosedur statistika yang diterapkan untuk meramalkan struktur probabilitas keadaan yang akan terjadi di masa yang akan datang dalam rangka pengambilan keputusan. Analisis data time series berarti memecah data lampau menjadi komponen-komponen dan memproyeksikannya ke depan (forecasting) (Hansun, 2012). Sehingga dapat disimpulkan bahwa analisis time series adalah urutan pengamatan berdasarkan interval waktu yang sama. Waktu yang digunakan dapat berupa hari, minggu, bulan, tahun, dan sebagainya dalam rangka pengambilan keputusan sebagai proyeksi untuk masa yang akan datang.

Salah satu metode baru dari analisi time series adalah Fuzzy Time Series yaitu menggabungkan logika Fuzzy dengan Analisis Time series. Konsep logika Fuzzy atau disebut dengan logika samar pertama kali diperkenalkan oleh Lotfi A. Zadeh dari University of California, Barkeley pada tahun 1965, yang merupakan alternatif dari logika tegas (crisp logic) (Fauziah, Wahyuningsih, dan Nasution, 2016). Berdasarkan hal tersebut pada penelitian ini akan digunakan Fuzzy Time Series untuk meramalkan jumlah Pengunjung di benteng Foert Rotterdam

\section{Tinjauan Pustaka}

\subsection{Logika Fuzzy}

Logika Fuzzy adalah metode yang dasarnya dari sistem kecerdasan buatan (Artificial Intelligence) yang dapat menirukan kemampuan manusia dalam berfikir ke dalam bentuk algoritma yang kemudian dijalankan oleh mesin. Algoritma ini digunakan dalam berbagai aplikasi pemrosesan data yang tidak dapat direpresentasikan dalam bentuk biner. Logika Fuzzy menginterpretasikan statemen yang samar menjadi sebuah pengertian yang logis. Fungsi Keanggotaan Fuzzy (Haris, 2010).

Fungsi keangotaan Fuzzy adalah suatu kurva yang menunjukkan pemetaan titik-titik input data dalam nilai keanggotaannya yang meiliki interval antara 0 sampai 1 . Untuk mendapatkan nilai keanggotaan, salah satu cara yang dapat dilakukan adalah pendekatan fungsi. Ada beberapa fungsi yang bisa digunakan.

\subsubsection{Representasi Kurva linear}

Pada representasi linier, pemetaan input ke derajat keanggotaannya digambarkan sebagai suatu garis lurus. Ada dua keadaan himpunan Fuzzy yang linear. Yaitu linear naik dan linear turun. Linear naik dimulai pada nilai domain yang memiliki derajat keanggotaan nol bergerak kekanan menuju ke nilai dominan yang memiliki derajat keanggotaan lebih tinggi.

Fungsi keanggotaan:

$$
(x)=\left\{\begin{array}{c}
0 ; x \leq a \\
(x-a) /(b-a) ; a \leq x \leq b \\
1 ; b \leq x \leq c
\end{array}\right.
$$

Linear Turun, garis lurus dimulai dari nilai domain dengan derajat keanggotaan tertinggi pada sisi kiri, kemudian bergerak menurun ke nilai domain yang memiliki derajat keanggotaan lebih rendah

Adapun fungsi keanggotannya adalah sebagai berikut:

$$
(x)=\left\{\begin{array}{c}
(b-x) /(b-a) ; a \leq x \leq b \\
0 ; x \geq b
\end{array}\right.
$$




\subsubsection{Repesentasi kurva Segitiga}

Kurva segitiga pada dasarnya merupakan gabungan dari dua garis linear yaitu garis linear naik dan garis linear turun.

Fungsi keanggotaan:

$$
(x)=\left\{\begin{array}{c}
0 ; x \leq a \text { atau } x \geq c \\
(x-a) /(b-a) ; a \leq x \leq b \\
(c-x) /(c-b) ; b \leq x \leq c
\end{array}\right.
$$

\subsubsection{Representasi Kurva Trapesium}

Kurva trapesium pada dasarnya seperti bentuk segitiga, hanya saja ada beberapa titik yang memiliki nilai keanggotaan 1 .

Fungsi keanggotaan:

$$
(x)=\left\{\begin{array}{c}
0 ; x \leq \text { a atau } x \geq c \\
(x-a) /(b-a) ; a \leq x \leq b \\
1 ; b \leq x \leq c \\
(c-x) /(c-b) ; b \leq x \leq c
\end{array}\right.
$$

\subsubsection{Representasi Kurva bentuk Bahu}

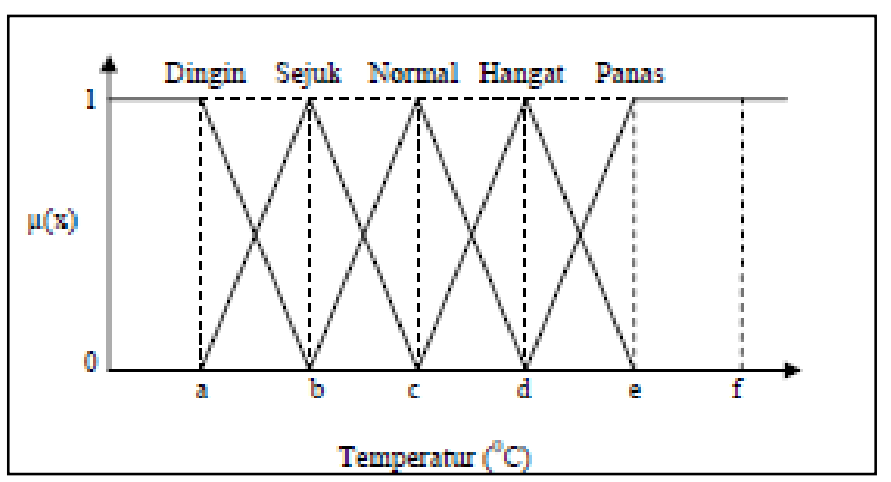

Gambar 1. Grafik Fungsi keanggotaan pada representasi Kurva Bahu

\subsection{Fuzzy time series}

Fuzzy time series adalah metode yang diperkenalkan oleh Song dan Chissom (1993), merupakan konsep baru untuk peramalan dengan menggunaakan logika Fuzzy, yaitu masalah peramalan time series yang mampu memberikan penjelasan pada data yang samar dan disajikan dalam nilai-nilai linguistik. Penggunaan metode Fuzzy time series sebelumnya telah dilakukan dalam beberapa penelitian, diantaranya penelitian yang dilakukan oleh Fauziah, Wahyuningsih, dan Nasution (2016) yang menggunakan analisis Fuzzy time series Chen dalam meramalkan curah hujan Kota Samarinda. Penelitian yang dilakukan oleh Susilowati dan Sulistijanti (2018) dengan judul Perbandingan Metode Fuzzy time series dengan Metode Box-Jenkins untuk memprediksi Jumlah Kunjungan Pasien Rawat Inap (Studi Kasus: Puskesmas Geyer Satu). Penelitian yang dilakukan oleh Tauryawati dan Irawan (2014) yang membandingkan metode Fuzzy time series Cheng dan metode Box-Jenkins untuk memprediksi IHSG. Penelitian yang dilakukan oleh Steven, Nurdianti, dan Bukhari (2018) yang berjudul perbandingan metode Fuzzy time series dan holt double exponential smoothing pada peramalan jumlah mahasiswa baru institut pertanian bogor. Pada penelitianpenelitian tersebut menunjukkan Fuzzy time series disarankan untuk digunakan karena cenderung mendapatkan nilai error yang kecil 
Langkah-langkah peramalan menggunakan Fuzzy time series model Chen (Chen, 1996) adalah sebagai berikut:

1. Menentukan Semesta Pembicaraan U (Universe of Discourse), selanjutnya dilakukan pembagian interval dengan jarak yang sama. Jika terjadi satu jumlah data dalam suatu interval lebih besar dari nilai rata-rata dari banyaknya data pada tiap interval, maka pada interval tersebut dibagi menjadi interval yang berukuran lebih kecil dengan membagi 2.

Rumus sebagai berikut (Chen, 1996):

Dimana:

$$
U=\left[X_{\min }-D_{1}, X_{\max }+D_{2}\right]
$$

$X_{\min }=$ Data minimum

$X_{\max }=$ Data maksimum

$D_{1}$ dan $D_{2}$ merupakan bilangan positif sembarang yang ditentukan oleh peneliti untuk menentukan himpunan semestanya dari himpunan data Historis.

2. Menentukan Jumlah Kelas

Salah satu metode yang dapat dgunakan untuk menentukan jumlah kelas adalah dengan melihat panjang interval yang efektif dengan metode berbasis rata-rata (average based). Langkah-langkah sebagai berijkut (Xihao dan Yimin, 2008):

a. Menghitung semua nilai absolut selisih antara $X_{t+1}$ dan $X_{t}(t=1, \ldots, n-1)$ sehingga diperoleh rata-rata nilai selisih absolut seperti berikut (Xihao dan Yimin, 2008):

$$
\text { Mean: } \frac{\sum_{i=1}^{n}|X t+1-x t|}{n}
$$

di mana:

$$
\begin{array}{ll}
\text { Mean } & \text { : nilai rata-rata } \\
n & \text { : jumlah observasi } \\
X t & \text { : data pada waktu ke-t }
\end{array}
$$

b. Menentukan setengah dari rata-rata yang diperoleh dari langkah pertama untuk kemudian dijadikan sebagai panjang interval dengan persamaan berikut (Xihao dan Yimin, 2008):

$$
\ell=\frac{\text { mean }}{2}
$$

dimana $\ell$ adalah panjang interval

c. Berdasarkan panjang interval yang diperoleh dari langkah (b), ditentukan basis dari panjang interval sesuai dengan tabulasi basis pada tabel 1. (Xihao dan Yimin, 2008)

Tabel 1. Tabel Basis Interval

\begin{tabular}{ll}
\hline Jangkauan & Basis \\
\hline $0,1-1,0$ & 0,1 \\
$1,1-10$ & 1 \\
$11-100$ & 10 \\
$101-1000$ & 100 \\
\hline
\end{tabular}

Panjang interval kemudian dibulatkan sesuai dengan tabel basis interval.

3. Mendefinisikan himpunan Fuzzy Ai dan melakukan fuzzifikasi pada data historis yang diamati.

Nilai derajat keanggotaan dari $\mu_{A i}\left(u_{i}\right)$ ditentukan berdasarkan aturan seperti dibawah ini (Chen, 1996):

Aturan 1 :Jika data historis $X_{t}$ termasuk dalam $u$ i, maka nilai derajat keanggotaan untuk $u$ i adalah 1 , dan $u_{\mathrm{i}}+1$ adalah 0,5 dan jika bukan $u_{\mathrm{i}}$ dan $u_{\mathrm{i}+1}$, berarti dinyatakan nol.

Aturan 2 :Jika data historis $X_{t}$ termasuk dalam $u_{i}, 1 \leq i \leq p$ maka nilai derajat keanggotaan untuk $u_{\mathrm{i}}$ adalah 1 , untuk $u_{\mathrm{i}}-1$ dan $u_{\mathrm{i}}+1$ adalah 0,5 dan jika bukan $u_{\mathrm{i}}, u_{\mathrm{i}}-1$ dan $u_{\mathrm{i}}+1$ berarti dinyatakan nol. 
Aturan 3 :Jika data historis $X_{t}$ termasuk dalam $u_{p}$, maka nilai derajat keanggotaan untuk $u_{\mathrm{p}}$ adalah 1 , untuk $u_{p}-1$ adalah 0,5 dan jika bukan $u_{\mathrm{p}}$ dan $u_{\mathrm{p}}-1$, berarti dinyatakan nol.

Misal $A_{1}, A_{2}, \ldots, A_{k}$ adalah himpunan $F u z z y$ yang mempunyai nilai linguistik dari suatu variabel linguistik, pendefinisian himpunan Fuzzy $A_{1}, A_{2}, \ldots, A_{k}$ pada semesta pembicaraan $U$ adalah sebagai berikut (Chen, 1996):

$A_{1}=1 / u_{1}+0.5 / u_{2}+0 / u_{3}+0 / u_{4}+0 / u_{5}+\ldots+0 / u_{p}$

$A_{2}=0.5 / u_{1}+1 / u_{2}+0.5 / u_{3}+0 / u_{4}+0 / u_{5}+\ldots+0 / u_{p}$

$A_{3}=0 / u_{1}+0.5 / u_{2}+1 / u_{3}+0.5 / u_{4}+0 / u_{5}+\ldots+0 / u_{p}$

.

$A p=0 / u_{1}+0 / u_{2}+0 / u_{3}+\ldots+0,5 / u_{p}-1+1 / u_{p}$

Dimana: $u_{i}(i=1,2, \ldots, p)$ adalah elemen dari himpunan semesta dan bilangan yang diberi simbol " " menyatakan derajat keanggotaan $\left.\mu_{A i}\left(u_{i}\right)\right)$ terhadap $A i(i=1,2, . ., p)$ yang di mana nilainya ialah $0,0,5$ atau 1.

4. Melakukan dan membuat tabel Fuzzy Logical Relationsip (FLR) berdasarkan data historis. Fuzzy logical relationship $A_{j} \rightarrow A_{k}$ berarti jika nilai enrollment pada tahun I adalah $\mathrm{A}_{\mathrm{j}}$ maka pada tahun $i+1$ adalah $A_{k} A_{j}$ sebagai sisi kiri relationship disebut sebagai current state dan $A_{k}$ sebagai sisi kanan relationship disebut sebagai next state. Dan jika terjadi perulangan hubungan maka tetap dihitung sekali.

5. Mengklasifikasikan FLR yang telah diperoleh dari tahap ke-3 ke dalam grup-grup sehingga terbentuk Fuzzy Logical Relationship Group (FLRG) dan mengkombinasikan hubungan yang sama.

6. Melakukan Defuzzifikasi yaitu proses perhitungan dari hasil output peramalan untuk kemudian dihitung sehingga mendapatkan hasil dari bilangan crisp, kemudian ditambahkan dengan data aktual pada waktu sebelumnya sehingga didapatkan hasil peramalan. Nilai peramalan pada metode Fuzzy time series model Chen terdapat beberapa aturan peramalan yang harus diperhatikan, antara lain:

Aturan 1: Jika hasil fuzzifikasi pada tahun ke t adalah Aj dan terdapat himpunan Fuzzy yang tidak mempunyai relasi logika Fuzzy, misal jika $A_{i} \rightarrow \emptyset$, dimana nilai maksimum fungsi keanggotannya dari $A i$ berada pada interval $\mathrm{u}_{\mathrm{i}}$ dan nilai tengah $\mathrm{u}_{\mathrm{i}}$ adalah $\mathrm{m}_{\mathrm{i}}$, maka hasil peramalan $F_{t+1}$ adalah $\mathrm{m}_{\mathrm{i}}$

Aturan 2: Jika hasil fuzzifikasi tahun ke $t$ adalah $u_{i}$ dan hanya terdapat satu FLR pada FLRG, misalnya jika $A_{i}$ $\rightarrow A_{j}$ di mana $A_{i}$ dan $A_{j}$ adalah himpunan $F u z z y$ dan nilai maksimum fungsi keanggotaan dari $A_{j}$ berada pada interval $u_{j}$ dan nilai tengah dari $u_{i}$ adalah $m_{j}$, maka hasil peramalan $F_{t+l}$ adalah $m_{i}$.

Aturan 3: Jika hasil fuzzifikasi pada tahun ke $t$ adalah $A_{j}$ dan $A j$ memiliki beberapa FLR pada FLRG, misalnya $A_{i} \rightarrow A_{j l}, A_{j 2}, \ldots, A_{j k}$ di mana $A_{i}, A_{j l}, A_{j 2}, \ldots, A j k$ adalah himpunan $F u z z y$ dan nilai maksimum fungsi keanggotaan dari $A_{j l}, A_{j 2}, \ldots, A_{j p}$ berada pada interval $u_{j 1}, u_{j 2}, \ldots$, ujk dan $m_{j l}, m_{j 2}, \ldots, m_{j k}$, maka hasil peramalan $F_{t+1}$ adalah sebagai berikut (Chen, 1996):

$$
F_{t+1}=\left(m_{j 1}+m_{j 2}+\ldots+m_{j k}\right) / \mathrm{k}
$$

Dimana $\mathrm{k}$ adalah jumlah nilai tengah dan untuk mencari nilai tengah $\left(\mathrm{m}_{\mathrm{i}}\right)$ pada interval Himpunan Fuzzy dapat digunakan persamaan berikut (Chen, 1996):

$$
m_{i}=\frac{(\text { batas atas }+ \text { batas bawah })}{2}
$$

\subsection{Ketepatan Metode Peramalan}

Model deret waktu dikatakan baik apabila telah mendekati dengan kenyataan. Hal tersebut dapat dilihat pada kesalahan (error) semakin kecil. Ketepatan model peramalan dapat dihitung dengan menggunakan Mean Absolute 
Percentage Error (MAPE) (Shim, 2000) dan Root Mean of Square Error (RMSE) (Shim, 2000), masing-masing rumusnya sebagai berikut:

$$
\mathrm{MAPE}=\sum_{t=1}^{n} \frac{\left|P E_{i}\right|}{n}
$$

Menurut Chang dkk (2007) kriteria MAPE di paparkan pada Tabel 2.

Tabel 2. Kriteria MAPE

\begin{tabular}{ll}
\hline MAPE & Keterangan \\
\hline$<10 \%$ & Kemampuan peramalan sangat baik \\
$10 \%-20 \%$ & Kemampuan peramalan baik \\
$20 \%-50 \%$ & Kemampuan peramalan cukup \\
$>50 \%$ & Kemampuan peramalan buruk \\
\hline
\end{tabular}

Keterangan:

$$
\mathrm{RMSE}=\sqrt{\frac{\sum_{t=1}^{n} e_{t}^{2}}{n}}
$$

$$
\begin{array}{ll}
e_{t} & =X_{t}-F_{t}=\text { kesalahan pada periode ke- } t \\
X_{t} & =\text { nilai data historis pada periode ke- } t \\
F_{t} & =\text { nilai ramalan pada periode ke- } t \\
P E_{i} & =\left(\frac{X_{t} \cdot F_{t}}{X_{t}}\right)(100) \\
n & =\text { banyaknya pengamatan }
\end{array}
$$

\subsection{Benteng Fort Rotterdam}

Benteng Fort Rotterdam adalah salah satu benteng yang ada di Kota Makassar, Sulawesi Selatan. Benteng ini dibangun pada 1545 oleh Raja Gowa ke-IX bernama Karaeng Tumapa'risi Kallonna dan dilanjutkan Raja Gowa ke-X yang bernama Imanrigau Daeng Bonto Karaeng Lakiung atau Karaeng Tunipalangga Ulaweng. Secara keseluruhan bangunan dalam Benteng Fort Rotterdam terdapat 16 bangunan termasuk satu bangunan yang didirikan pada jaman Jepang, serta memiliki 5 bastion, yakni Bastion Bone, Bacan, Amboina, Mandarsyah, dan Buton (Balai Pelestarian Cagar Budaya Makassar, 2013)

\section{Metode Penelitian}

Dalam menganalisis data penelitian ini, penulis menyusun langkah-langkah sebagai berikut :

1. Analisis Statistika Deskriptif

2. Metode Fuzzy Time series model Chen Langkah-langkah analisis :

a. Menentukan semesta pembicaraan U (Universe of Discourse).

b. Menentukan Jumlah dan Panjang kelas interval dengan menggunakan interval berbasis rata-rata.

c. Menentukan defuzzifikasi dan mendefinisikan himpunan Fuzzy pada U.

d. Melakukan fuzzifikasi pada data jumlah pengunjung Bentteng Fort Rotterdam.

e. Mengklasifikasikan Fuzzy logic relationship (FLR)

f. Mengklasifikasikan FLR ke dalam kelompok-kelompok sehingga terbentuk Fuzzy Logical Relationship Group (FLRG).

g. Melakukan proses defuzzifikasi dan melakukan perhitungan peramalan jumlah pengunjung Benteng Fort Rotterdam berdasarkan aturan-aturan peramalan. 


\section{Hasil dan Pembahasan}

\subsection{Deskripsi Data Penelitian}

Penelitian dilakukan untuk mengimplementasikan metode Fuzzy time series yang dibandingkan dengan metode ARIMA dalam meramalan jumlah pengunjung di Benteng Fort Rotterdam. Data yang digunakan merupakan data bulanan Jumlah pengunjung di Benteng Fort Rotterdam selama 84 periode dimulai Januari 2012 hingga Desember 2018, yang diperoleh dari Balai Pelestari Cagar Budaya (BPCB) Sulsel yang khusus mengawasi Benteng Fort Rotterdam. Plot data jumlah pengunjung maka didapatkan bentuk grafik seperti gambar 1.

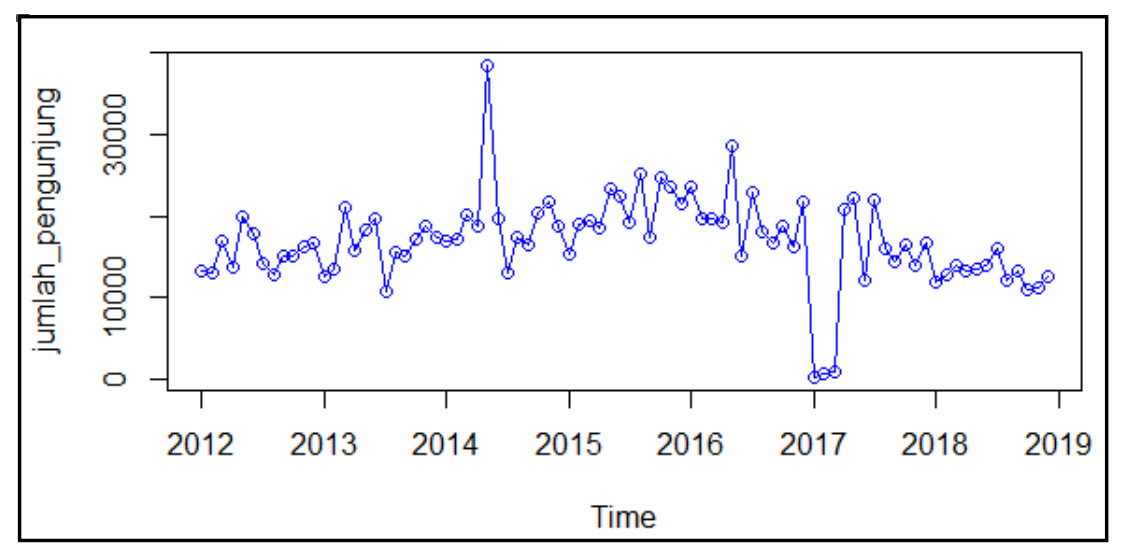

Gambar 1. Grafik Jumlah Pengunjung Benteng fort Rotterdam

Pada grafik gambar 1 dapat dilihat jumlah pengunjung Benteng Fort dari Januari hingga April 2014 bergerak antara 1000 dan 2000, kemudian melonjak naik pada Mei 2014. Data kembali bergerak antara 1000 dan 3000 mulai Juni 2014 hingga Desember 2016 dan menurun drastis pada tiga bulan selanjutnya yaitu Januari-Maret 2017. Setelah itu jumlah pengunjung dari Benteng Fort Rotterdam kembali bergerak antara 1000 dan 2000.

Tabel 3. Statistik Deskriptif Data Jumlah Pengunjung Benteg Fort Rotterdam

\begin{tabular}{lr}
\hline & Statistik \\
\hline Minimum & 259 \\
Maximum & 38532 \\
Jangkauan & 38273 \\
Mean & 16943 \\
Median & 16819 \\
\hline
\end{tabular}

Dari Januari 2012 sampai dengan Desember 2018, rata-rata pengunjung Benteng Fort Rotterdam sebesar 16943 orang dengan pengunjung terbanyak sebesar 38532 orang yang terjadi pada Mei 2014. Sedangkan Jumlah pengunjung yang paling sedikit yaitu 259 yang terjadi pada bulan Januari 2017.

\subsection{Penggunaan Metode Fuzzy Time Series untuk Meramalkan Jumlah Pengunjung di Benteng Fort Rotterdam}

Peramalan dengan metode Fuzzy time series yang dilakukan dalam penelitian ini menggunakan 84 data historis. Data historis tersebut merupakan data bulanan jumlah pengunjung Benteng Fort Rotterdam pada periode Januari 2012 hingga Desember 2018. Peramalan dilakukan untuk menduga jumlah pengunjung pada periode selanjutnya. Tahapan Peramalan dalam penelitian ini adalah mendefinisikan semesta pembicaraan $U$, menentukan jumlah dan Panjang kelas interval, defuzzifikasi dan mendefenisikan himpunan Fuzzy pada $U$, melakukan Fuzzifikasi pada data jumlah pengunjung, menentukan Fuzzy logic relationship (FLR), membentuk Fuzzy Logical Relationship Group (FLRG), melakukan defuzzifikasi, dan melakukan perhitungan peramalan. 
1. Mendefinisikan semesta pembicaraan U (Universe of Discourse).

Menentukan semesta Pembicaraan $U$. Data jumlah pengunjung yang berkunjung ke Benteng Fort Rotterdam memiliki nilai minimum 259 sedangkan nilai maksimum 38532. Berdasarkan semesta pembicaraan dengan menggunakan data minimum dan data maksimum semua data telah termasuk dalam semua interval yang terbentuk, namun jumlah kelas yang akan dibentuk sebanyak 21 maka ditentukan $D_{1}=0$ dan $D_{2}=2000$, Sehingga diperoleh semesta pembicaraan yaitu $U=[259-0,38532+0]=[259 ; 40532]$.

2. Penentuan Jumlah Kelas Interval dengan menggunakan interval berbasis rata-rata.

Salah satu metode yang dapat dgunakan untuk menentukan jumlah kelas adalah dengan melihat panjang interval yang efektif dengan metode berbasis rata-rata (average based), langkah awal adalah menghitung nilai absolut selisih, kemudian menentukan rata-ratanya. Pada penelitian ini diketahui nilai absolut selisih adalah 3890,46 yang dibagi dua menjadi 1945,23, selanjutnya dibulatkan sesuai dengan Table Basis interval pada Tabel 2.1 menjadi 1900. Berdasarkan Panjang interval yang diperoleh jumlah kelas dapat ditentukan dengan membagi jangkauan semesta pembicaraan dengan Panjang interval efektif. Diketahui jangkauan 40273, sehingga:

$$
\text { jumlah kelas }=\frac{40273}{1945,23}=21,19
$$

dibulatkan menjadi 21 kelas interval. Kelas Interval yang dibentuk adalah sebagai berikut:

$$
\begin{array}{lll}
u_{1}=[259,000 ; 2176,762] & u_{8}=[13683,333 ; 15601,095] & u_{15}=[27107,667 ; 29025,429] \\
u_{2}=[2176,762 ; 4094,524] & u_{9}=[15601,095 ; 17518,857] & u_{16}=[29025,429 ; 30943,190] \\
u_{3}=[4094,524 ; 6012,286] & u_{10}=[17518,857 ; 19436,619] & u_{17}=[30943,190 ; 32860,952] \\
u_{4}=[6012,286 ; 7930,048] & u_{11}=[19436,619 ; 21354,381] & u_{18}=[32860,952 ; 34778,714] \\
u_{5}=[7930,048 ; 9847,810] & u_{12}=[21354,381 ; 23272,143] & u_{19}=[34778,714 ; 36696,476] \\
u_{6}=[9847,810 ; 11765,571] & u_{13}=[23272,143 ; 25189,905] & u_{20}=[36696,476 ; 38614,238] \\
u_{7}=[11765,571 ; 13683,333] & u_{14}=[25189,905 ; 27107,667] & u_{21}=[38614,238 ; 40532,000]
\end{array}
$$

\section{Defuzzifikasi dan Mendefinisikan Himpunan Fuzzy Pada $U$}

Proses pendefinisian himpunan Fuzzy pada $U$ dapat dilakukan dengan melihat Persamaan (2.6) berdasarkan interval yang terbentuk sebanyak 21 , yaitu $u_{1}, u_{2}, u_{3}, u_{4}, u_{5}, u_{6}, u_{7}, u_{8}, u_{9}, u_{10}, u_{11}, u_{12}, u_{13}, u_{14}, u_{15}, u_{16}, u_{17}, u_{18}, u_{19}$, $u_{20}$, dan $u_{21}$. Hasil pendefinisian himpunan $F u z z y$ pada $U$, frekuensi data historis masing-masing interval dan hasil fuzzifikasi disajikan pada tabel 4. Terdapat tiga data historis pada interval $\mathrm{u}_{1}$ dengan Fuzzifikasi $A_{l}$. Frekuensi tertinggi ada pada interval $u_{9}$ yaitu sebanyak 18 dan frekuensi terendah ada pada $u_{2}, u_{3}, u_{4}, u_{5}, u_{14}, u_{16}, u_{17}, u_{18}, u_{19}$, dan $u_{21}$ yaitu 0.

Tabel 4. Fuzzifikasi Sub-sub Interval dari U

\begin{tabular}{lcc}
\hline Sub-sub interval dari $U$ & Frekuensi & Fuzzifikasi \\
\hline u1 $=[259,000 ; 2176,762]$ & 3 & A1 \\
u2 $=[2176,762 ; 4094,524]$ & 0 & A2 \\
u3 $=[4094,524 ; 6012,286]$ & 0 & A3 \\
$:$ & & \\
u19 $=[34778,714 ; 36696,476]$ & 0 & A19 \\
u20=[36696,476;38614,238] & 1 & A20 \\
u21 $=[38614,238 ; 40532,000]$ & 0 & A21 \\
\hline
\end{tabular}

4. Melakukan fuzzifikasi pada data jumlah pengunjung Bentteng Fort Rotterdam.

Fuzzifikasi merupakan proses mengidentifikasi data historis kedalam Fuzzy set. Jika $\mathrm{F}_{\mathrm{t}}$ berada pada Himpunan Fuzzy set $A_{k}$ maka $F_{t}$ akan difuzzifikasikan sebagai $A_{k}$. Sebagai contoh untuk waktu Januari 2012 dengan data Historis 13241 yang berada pada Fuzzy set $\mathrm{A}_{7}$ maka difuzzifikasikan seabagai $\mathrm{A}_{7}$. Fuzzifikasi masing-masing data Historis dapat dilihat pada Tabel 5. 
Tabel 5. fuzzifikasi pada data historis

\begin{tabular}{|c|c|c|}
\hline Waktu & Data & Fuzzyfication \\
\hline Jan-2012 & 13241 & $A_{7}$ \\
\hline Feb-2012 & 13090 & $A_{7}$ \\
\hline$\vdots$ & & $\vdots$ \\
\hline Okt-2018 & 11030 & $A_{6}$ \\
\hline Nov-2018 & 11191 & $A_{6}$ \\
\hline Des-2018 & 12625 & $A_{7}$ \\
\hline
\end{tabular}

5. Menentukan Fuzzy logic relationship (FLR)

Relationship ditentukan berdasarkan nilai fuzzifikasi dari data historis jika $F_{t-1}$ difussifikasikan sebagai $A_{i}$ dan $F_{t}$ sebagai $A_{j}$, maka $A_{i}$ berelasi dengan $A_{j}$. Sebagai contoh pada waktu Januari 2012 fuzzifikasinya $A_{7}$ dan Februari 2012 Fuzzifikasinya $A_{7}$ sehingga Fuzzy Logic relationship (FLR) bulan Januari 2012 ke Feruari 2012 adalah $A_{7} \rightarrow A_{7}$. Secara keseluruhan FLR yang terbentuk berdasarkan data historis dari 84 bulan untuk pengunjung Benteng Fort Rotterdam disajikan pada tabel 4.5. FLR yang terbentuk sebanyak 83 karena jumlah data Historis sebanyak 84 masing-masing akan berelasi sehingga untuk Januari 2012, tidak memiliki data sebelumnya maka tidak ada yang berelasi, maka FLR yang terbentuk langsung dilakukan pada bulan Februari 2012 dengan $F_{t-1}$ adalah Fuzzifikasi pada bulan Januari 2012 dan dan $F_{t}$ adalah Februari 2012.

\begin{tabular}{lc}
\multicolumn{2}{l}{ Tabel 6. Fuzzy Logical Relationship (FLR) } \\
\hline NO & FLR \\
\hline 1 & $A_{7} \rightarrow A_{7}$ \\
2 & $A_{7} \rightarrow A_{9}$ \\
3 & $A_{9} \rightarrow A_{8}$ \\
$\vdots$ & $\vdots$ \\
81 & $A_{7} \rightarrow A_{6}$ \\
82 & $A_{6} \rightarrow A_{6}$ \\
83 & $A_{6} \rightarrow A_{7}$ \\
\hline
\end{tabular}

Pada Tabel 6. diketahui beberapa jenis relasi seperti pada bulan Januari 2012 dengan Februari $2012 A_{7} \rightarrow A_{7}$, artinya fuzzifikasi pada bulan Januari adalah $A_{8}$ dan fuzzifikasi untuk waktu selanjutnya Februari adalah $A_{8}$ hal ini mengindikasikan bahwa jumlah pengunjung pada bulan Januari dan Februari berasal dari kelas Interval yang sama. Untuk waktu Februari yang berelasi dengan Maret $A_{7} \rightarrow A_{9}$, artinya Februari berasal dari interval yang berbeda, Februari yang berasal dari $u_{7}$ dan Maret berasal dari $u_{9}$. Penjelasan yang sama untuk relasi yang lain

6. Mengklasifikasikan FLR ke dalam kelompok-kelompok sehingga terbentuk Fuzzy Logical Relationship Group (FLRG)

FLRG dilakukan dengan cara mengelompokkan Himpunan Fuzzy yang memiliki Current state sama. Setelah itu dikelompokkan menjadi satu kelompok berdasarkan FLR pada tabel 4.5. Sebagai contoh untuk relasi $A_{1}$, yaitu $A_{l} \rightarrow$ $A_{1}, A_{l} \rightarrow A_{11}$, maka FLRG yang terbentuk adalah $A_{l} \rightarrow A_{l}, A_{1 l}$. Secara keseluruhan FLRG yang diperoleh berdasarkan FLR yang terbentu disajikan pada tabel 4.5. Pada penentuan FLRG meskipun terjadi perulangan hubungan tetap dihitung sekali, sebagai contoh relasi $A_{l} \rightarrow A_{l}$ muncul dua kali yaitu pada nomor 61 dan 62 .

Tabel 7. Fuzzy Logical Relationship Group (FLRG)

\begin{tabular}{|c|c|c|c|}
\hline Grup & & si Logika Fuzzy & No. FLR \\
\hline 1 & A1 & $\rightarrow \quad \mathrm{A} 1, \mathrm{~A} 11$ & 61,62 , dan 63 \\
\hline 2 & A2 & $\rightarrow \varnothing$ & \\
\hline 3 & A3 & $\rightarrow \varnothing$ & \\
\hline
\end{tabular}




\begin{tabular}{clll}
\hline Grup & \multicolumn{2}{c}{ Relasi Logika Fuzzy } & No. FLR \\
\hline 19 & A19 & $\rightarrow \varnothing$ \\
20 & A20 & $\rightarrow$ A11 & \\
21 & A21 & $\rightarrow \varnothing$ & \\
\hline
\end{tabular}

7. Melakukan proses defuzzifikasi dan melakukan perhitungan peramalan jumlah pengunjung Benteng Fort Rotterdam berdasarkan aturan-aturan peramalan.

Ada dua tahap dalam proses defuzzifikasi yaitu yang pertama, mencari nilai tengah dari masing-masing interval berdasarkan persamaan 2.6 dan kedua, menghitung peramalan berdasarkan tiga aturan defuzzifikasi. Penentuan nilai tengah diperoleh dari jumlah nilai minimum dan nilai maksimal dari masing-masing interval kemudian dibagi 2. Misalnya nilai tengah dari $u_{l}$ diperoleh dengan cara sebagai berikut:

Nilai tengah $u_{1}=\frac{259,00+2176,76}{2}=1217,88$

Nilai tengah dari masing-masing interval disajikan pada tabel 8.

Tabel 8. Nilai Tengah masing-masing Interval

\begin{tabular}{crc}
\hline Interval & Fuzzifikasi & Nilai Tengah \\
\hline $\mathrm{u} 1=[259,000 ; 2176,762]$ & A1 & 1217,88 \\
$\mathrm{u} 2=[2176,762 ; 4094,524]$ & A2 & 3135,64 \\
$\mathrm{u} 3=[4094,524 ; 6012,286]$ & A3 & 5053,41 \\
& & \\
$\mathrm{u} 19=[34778,714 ; 36696,476]$ & A19 & 35737,59 \\
$\mathrm{u} 20=[36696,476 ; 38614,238]$ & A20 & 37655,36 \\
$\mathrm{u} 21=[38614,238 ; 40532,000]$ & A21 & 39573,12 \\
\hline
\end{tabular}

Setelah mengetahui nilai tengah masing-masing interval, dilanjutkan tahap selanjutnya yaitu menghitung peramalan berdasarkan tiga aturan defuzzifikasi, maka diperoleh hasil defuzzifikasi berdasarkan FLRG yang disajikan pada tabel 9.

Tabel 9. Hasil Defuzzifikasi FLRG

\begin{tabular}{ll|lll|l}
\hline \multicolumn{4}{l}{ Peramalan Jumlah Pengunjung Benteng } & Fort Rotterdam \\
\hline A1 & $\rightarrow 10806,69$ & A8 & $\rightarrow 17518,86$ & A15 $\rightarrow 14642,21$ \\
A2 & $\rightarrow 3135,64$ & A9 & $\rightarrow 18477,74$ & A16 $\rightarrow 29984,31$ \\
A3 $\rightarrow 5053,41$ & A10 $\rightarrow 22861,20$ & A17 $\rightarrow 31902,07$ \\
A4 & $\rightarrow 6971,17$ & A11 $\rightarrow 16879,60$ & A18 $\rightarrow 33819,83$ \\
A5 & $\rightarrow 8888,93$ & A12 & $\rightarrow 14642,21$ & A19 $\rightarrow 35737,59$ \\
A6 & $\rightarrow 13363,71$ & A13 $\rightarrow 20874,94$ & A20 $\rightarrow 20395,50$ \\
A7 & $\rightarrow 16240,35$ & A14 $\rightarrow 26148,79$ & A21 $\rightarrow 39573,12$ \\
\hline
\end{tabular}

Hasil defuzzifikasi pada tabel 9 dapat diketahui hasil peramalan jumlah pengunjung benteng Fort Rotterdam dari bulan Januari 2012 sampai dengan Desember 2018 serta hasil ramalan untuk waktu selanjutnya. Sebagai contoh untuk meramalkan bulan Februari 2012, pada bulan Januari 2018 difuzzifikasikan $A_{7}$ yang termasuk kedalam interval $u_{7}=[11765,57 ; 13683,33]$ maka derajat tertinggi berada pada $u_{7}$. kemudian direlasikan diketahui bahwa $A_{7}$ memiliki 6 FLR $\left(A_{7} \rightarrow A_{6}, A_{7} \rightarrow A_{7}, A_{7} \rightarrow A_{8}, A_{7} \rightarrow A_{9}, A_{7} \rightarrow A_{11}, A_{7} \rightarrow A_{12}\right)$ yang terjelaskan pada tabel 4.5, maka dapat ditentukan peramalan berdasarkan aturan fuzzifikasi yaitu $A_{7}$ memiliki 7 FLRG. Masing-masing next state memiliki nilai tengah 10806,69, 12724,45, 14642,21, 16559,97, 20395,50, dan 22313,26. Dari 6 nilai tengah dijumlahkan kemudian dibagi 6 sehingga diperoleh 16240,35. Sehingga ramalan untuk waktu Februari 2018 adalah 16240,35. Hasil ramalan disajikan pada tabel 10. 
Tabel 10. Hasil Ramalan

\begin{tabular}{cclc}
\hline Tahun & Actual & Fuzzifikasi & Ramalan \\
\hline Jan-12 & 13241 & $A_{7}$ & \\
Feb-12 & 13090 & $A_{7}$ & 15750,45 \\
Mar-12 & 16870 & $A_{9}$ & 15750,45 \\
$\vdots$ & $\vdots$ & & $\vdots$ \\
Okt-18 & 11030 & $A_{6}$ & 16240,35 \\
Nov-18 & 11191 & $A_{6}$ & 13363,71 \\
Des-18 & 12625 & $A_{7}$ & 13363,71 \\
Jan-19 & & & 16240,35 \\
\hline
\end{tabular}

Tabel lengkap hasil peramalan jumlah pengunjung Benteng Fort Rotterdam dapat dilihat pada lampiran 2. Ramalan melihat fuzzifikasi data sebelumnya sehingga peramalan Jumlah pengunjung Benteng Fort rotterdan untuk bulan Januari 2019 menggunakan fuzzifikasi bulan Desember 2018 yaitu $A_{7}$ dengan hasil peramalan sebesar 16240,3.

Grafik data aktual dan data peramalan dapat dilihat pada gambar 3.

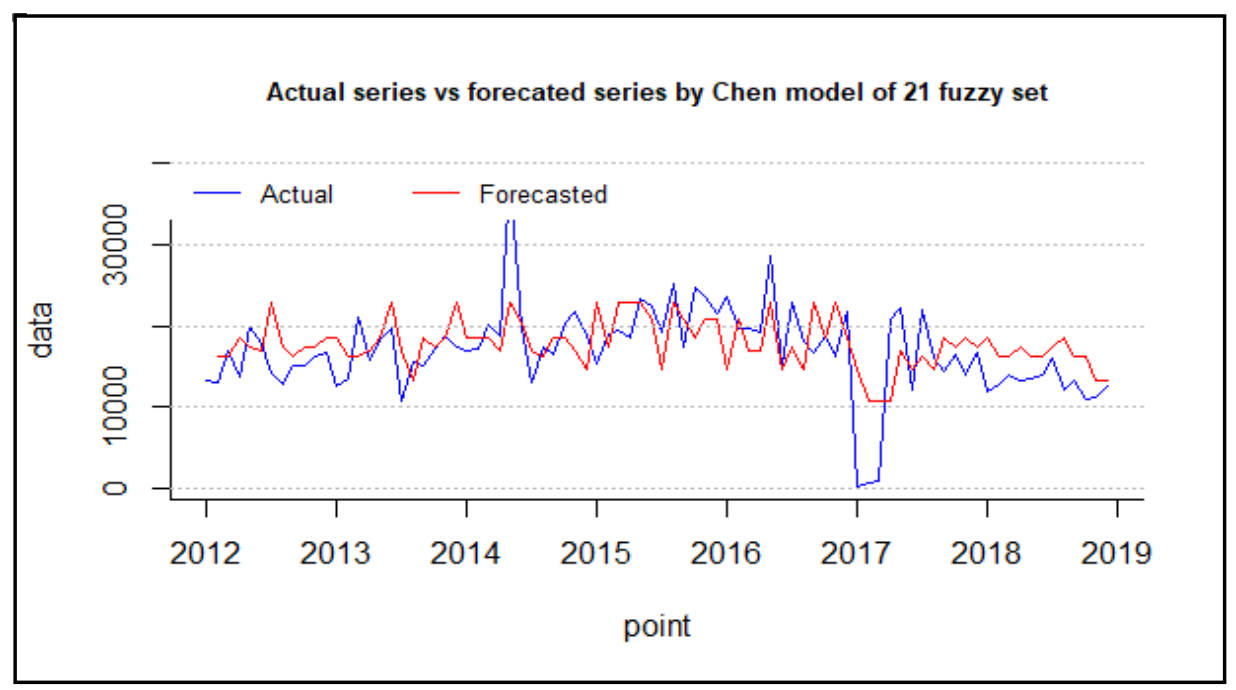

Gambar 3. Grafik Perbandingan Data Aktual dan Data Peramalan

\section{Kesimpulan}

Hasil analisis peramalan jumlah pengunjung di Benteng Fort Rotterdam menggunakan metode Fuzzy Time series pada bulan selanjutnya adalah 16240,35, dengan RMSE $=4739,08$ dan MAPE $=119,93$. Berdasarkan hasil penelitian maka saran yang dapat disampaikan adalah sebagai berikut:

1. Menggunakan metode Fuzzy Time Series untuk meramalkan jumlah pengunjung pada tempat lain.

2. Melakukan analisis perbandingan metode Fuzzy time series dengan metode yang lain.

\section{References}

Aswi \& Sukarna. 2006. Analisis Deret Waktu: Teori dan Aplikasi. Makassar: Andira Publisher.

Balai Pelestarian Cagar Budaya Makassar. 2013. Bangunan Bersejarah di Kota Makassar.

Chang, P. C., Wang, Y. W., \& Liu, C. H. (2007). The development of a weighted evolving fuzzy neural network for PCB sales forecasting. Expert Systems with Applications, 32(1), 86-96. 
Chen, S. M. (1996). Forecasting enrollments based on fuzzy time series. Fuzzy sets and systems, 81(3), 311-319.

Fauziah, N., Wahyuningsih, S., \& Nasution, Y. N. (2016). Peramalan Mengunakan Fuzzy Time Series Chen (Studi Kasus: Curah Hujan Kota Samarinda). Jurnal Statistika Universitas Muhammadiyah Semarang, 4(2).

Hansun, S. (2012). Peramalan data IHSG menggunakan fuzzy time series. IJCCS (Indonesian Journal of Computing and Cybernetics Systems), 6(2).

Haris, M. S. (2010). Implementasi Metode Fuzzy Time Series dengan penentuan interval berbasis rata-rata untuk peramalan data penjualan bulanan. Skripsi tidak dipublikasikan. Malang: Universitas Brawijaya Malang.

Ibo, A. 2018. Sektor Pariwisata Jadi Investasi Unggulan di 2018 . https://ww w.liputan6.com/lifestyle/read/3217850/sektor-pariwisata-jadi-investasi-unggulan-di-2018. Diakses tanggal 5 februari 2019.

Kassa, N. N. (2017). Peramalan Jumlah Pengunjung Objek Wisata Benteng Fort Rotterdam dengan Metode Dekomposisi (Doctoral dissertation, FMIPA).

Shim, J. K. 2000. Strategic Business Forecasting: The Complete Guide to Forecasting Real WorldCompany performance. New York: St. Lucies Press.

Song, Q., \& Chissom, B. S. (1993). Forecasting enrollments with fuzzy time series—part I. Fuzzy sets and systems, 54(1), 1-9.

Steven, S., Nurdiati, S., \& Bukhari, F. (2018). Perbandingan Metode Fuzzy Time Series dan Holt Double Exponential Smoothing Pada Peramalan Jumlah Mahasiswa Baru Institut Pertanian Bogor. Jurnal Matematika Dan Aplikasinya, 12(2).

Susilowati, S., \& Sulistijanti, W. (2018). Perbandingan Metode Fuzzy Time Series dengan Metode Box-Jenkins untuk Memprediksi Jumlah Kunjungan Pasien Rawat Inap (Studi Kasus: Puskesmas Geyer Satu). Proceeding of The URECOL, 61-73.

Tauryawati, Mey Lista., M. Isa Irawan. 2014. Perbandingan Metode Fuzzy Time Series Cheng dan Metode BoxJenkins untuk Memprediksi IHSG. Jurnal Sainns dan Seni Pomits. Vol. 3 N0. 2.

Nawangwulan, Maya 2014. Pariwisata Indonesia Unggul di Budaya dan Alam. https://bisnis.tempo.co/read/558179/pariwisata-indonesia-unggul-di-budaya-dan-alam/full\&view=ok. Diakses tanggal 5 februari 2019.

Wei, William WS. 2006. Time Series Analysis. New York: Pearson Addison Wesley.

Xihao, S., \& L. Yimin. 2008. Average-Based Fuzzy Time Series Models for Forecasting Shanghai Compound Index. World Journal of Modelling and Simulation. Vol. 4: 104-111. 